\title{
A self-novelty manipulation of self-focused attention for Internet and laboratory experiments
}

\author{
PAUL J. SILVIA \\ University of North Carolina, Greensboro, North Carolina \\ and \\ JAN EICHSTAEDT \\ Universität der Bundeswehr Hamburg, Hamburg, Germany
}

\begin{abstract}
Conventional manipulations of self-focused attention are poorly suited for Internet experiments and for group-based administration. The authors present a self-novelty manipulation that effectively induces self-awareness for such contexts. In the high self-focus condition, people write about how they differ from their family and friends and from people in general. In the control conditions, people write about neutral topics or do no writing. Three experiments using different measures of self-focus (the situational self-awareness scale, a pronoun selection task, and the private self-consciousness scale) showed that the self-novelty manipulation significantly increased self-focused attention. This effect appeared in Internet-based experiments (Experiment 1) and in laboratory experiments with groups (Experiments 2 and 3). The self-novelty manipulation appears promising for self-awareness research conducted outside of conventional laboratory contexts.
\end{abstract}

Since the early 1970 s, psychologists have been intrigued by the effects of self-focused attention on social behavior (Duval \& Wicklund, 1972). People can focus attention on the self and, thus, monitor their thoughts and actions in relation to their personal standards (Duval \& Silvia, 2001; Silvia \& Duval, 2001a). The meta-cognitive skill of selfawareness is shared by few other species (Hyatt \& Hopkins, 1994; Povinelli \& Prince, 1998), and it has important implications for social, cognitive, and clinical issues (Ingram, 1990; Silvia \& Duval, 2004; Spurr \& Stopa, 2002).

Self-awareness is usually manipulated by arranging the environment in a way that makes the person salient. For example, people can sit at a desk facing a mirror that reflects the face and upper body (e.g., Duval \& Wicklund, 1973; Silvia, 2002a). Other studies place a video camera directly in front of the participant and display the recorded images on a monitor next to the participant. When the participants look at the monitor, they see themselves looking off to the side (Duval \& Lalwani, 1999; Duval \& Silvia, 2002; Silvia \& Duval, 2001b; Silvia \& Phillips, 2004). Some studies have introduced confederates who observe the participant (Carver \& Scheier, 1978). Early studies played a recording of the participant's voice or another person's voice (Ickes, Wicklund, \& Ferris, 1973; Wicklund

We thank Julia Whitacre for her assistance with data collection. The selfnovelty manipulation can be downloaded from P.J.S.'s Web site: http://www. uncg.edu/ p_silvia/. Correspondence should be addressed to P. J. Silvia, Department of Psychology, P. O. Box 26170, University of North Carolina, Greensboro, NC 27402-6170, or to J. Eichstaedt, Universität der Bundeswehr Hamburg, Holstenhofweg 85, D-22039 Hamburg, Germany (e-mail: p_silvia@uncg.edu or jan.eichstaedt@unibw-hamburg.de).
\& Duval, 1971), although this manipulation fell out of favor because justifying the recording and playback requires a complex procedure. Mirrors and video cameras are the most popular manipulations in contemporary selfawareness research.

These manipulations, however, are impractical for many research contexts. Researchers interested in Internet-based studies of self-awareness cannot use manipulations based on mirrors, video cameras, or audiotape. Researchers who prefer to run groups of participants cannot use conventional manipulations either. Experiments conducted over the Internet or in groups need an alternative manipulation of self-focused attention. This article describes a new manipulation of self-focused attention based on self-novelty, presents some validation evidence, and reviews findings from past studies that have used the manipulation.

\section{A SELF-NOVELTY MANIPULATION}

One way to increase self-focused attention is to make people feel distinctive. Attention gravitates toward novel, distinctive, and salient stimuli (Koffka, 1935). When people stand out in some way, they will focus attention on the self. The salient self-aspect need not be especially important or personally significant. A lot of self-awareness research has shown that perceiving the self as distinctive increases selffocused attention (Snow, Duval, \& Silvia, in press; for a review, see Duval \& Silvia, 2001, chap. 2). Several laboratory studies have used this principle as a basis for manipulating self-awareness. In one experiment, people were told that their astrological pattern was either very unusual or quite common (Mayer, Duval, Holtz, \& Bowman, 1985). 
This manipulation increased self-focus, as measured by the self-focus Stroop task (Geller \& Shaver, 1976). Feeling distinctive in the sense of minority status within a group also affects self-focused attention (Mullen, 1983; Wegner \& Schaefer, 1978).

A simple, direct way to manipulate self-novelty is to ask the person to describe ways in which he or she differs from others. This gets the person actively involved in perceiving differences between self and others, and it should thus increase self-focus. The advantage of a writing task is that it could be administered over the Internet - people could easily complete self-descriptions in text fields. Writing tasks are also well suited to group administration, since the manipulation is easily integrated into other questionnaires and procedures. Demonstrating the validity of such a manipulation is critical, of course, because manipulating feelings of distinctiveness could manipulate processes other than self-awareness. We thus will describe three validation experiments in which the manipulation is developed and its effects are considered.

\section{EXPERIMENT 1 Internet Context}

In the first experiment, we explored the viability of a selfnovelty manipulation for Internet-based research. Participants completed the self-novelty manipulation along with self-report measures of self-focused attention. This enabled us to look at whether the manipulation effectively creates different levels of self-focus within an on-line data collection environment.

\section{Method}

Participants and Design. A total of 90 people participated voluntarily over the Internet. No incentives were offered (e.g., raffles). The study was announced solely through a link on the American Psychological Society's Web page of links to Internet studies (http://psych. hanover.edu/aps/exponnet.html). Each person was assigned randomly to one of two conditions: a self-novelty condition or a control condition. The participants in the self-novelty condition first received the self-novelty manipulation and then answered the situational selfawareness scale (Govern \& Marsch, 2001). The participants in the control condition first answered the situational self-awareness scale and then completed the self-novelty task. Both conditions were thus kept equally time consuming, thereby minimizing different dropout rates between conditions. Dropout rates were equivalent between the conditions (34\% in the self-novelty condition, $37 \%$ in the control condition) and were similar to dropout rates for other Internet-based experiments of equivalent length and complexity (see O'Neil \& Penrod, 2001; O'Neil, Penrod, \& Bornstein, 2003; Reips, 2002b). Each experiment was approved by the necessary IRB.

Materials. Web pages were created using plain HTML (see Krantz \& Eagley, 1996) for the descriptions of the study and HTML-forms (thereby also using JavaScript) for the participants' data entry. Text area control elements were used for the self-novelty writing task. Groups of radio control elements were used for the dependent measures, forming 7-point response scales for the situational self-awareness scale (Govern \& Marsch, 2001). We thus converted the original paperand-pencil scale to a Web-based format. Given past research (R. N. Davis, 1999; Pasveer \& Ellard, 1998; Pettit, 2002), both versions should be equivalent. CGI scripts (Kieley, 1996) programmed in Perl (Schwartz, 1998) handled the incoming data on the server.
Procedure. Upon arriving at the experiment, the participants read a consent page that described the experiment's general purposes and approximate length and assured the anonymity of the responses. The experiment - entitled "Personality and Uniqueness"-concerned "personality and people's beliefs about how they differ from other people." The participants who wanted to continue clicked a button to start the experiment. At this point, the participants were randomly assigned to one of two conditions. In the self-novelty condition, people received a new page containing the self-novelty writing task. Specifically, people responded to three questions (via text area control elements): (1) What is it about you that makes you different from your family? (2) What is it about you that makes you different from your friends? and (3) What is it about you that makes you different from people in general? People in the control condition completed the dependent measures before completing the self-novelty writing task. The open-ended responses were recorded but not coded, apart from checking that people completed each question.

The dependent measure was the situational self-awareness scale (Govern \& Marsch, 2001). This nine-item scale assesses momentary levels of self-focused attention. It has three three-item subscales: private self-aspects (e.g., "Right now, I am conscious of my inner feelings"), public self-aspects (e.g., "Right now, I am self-conscious about the way I look"), and external surroundings (e.g., "Right now, I am conscious of what is going on around me"). No items are reverse scored. Each item was accompanied by a response scale that ranged in seven equidistant points from 1 (strongly disagree) to 7 (strongly agree). The private subscale was the main dependent measure in this experiment. People also indicated their gender ( $f e-$ male or male), whether English was their first language (yes or no), their education level (high school or less, some college, college graduate, master's degree or doctoral degree), their age, and their current country of residence. A final item invited comments about the experiment.

After clicking a button to submit the data, the participants were taken to a Web page that thanked them for their participation, explained the experiment in more detail, and presented preliminary findings. Links to other Internet studies and to Web pages about personality were provided as well. The date, time, and remote address of the data submission were collected, along with the survey data. Because the data were submitted before the participant learned the experiment's hypotheses, people could not click back to the experiment and modify their data without being easily detected. Such cases would appear as two adjacent data submissions with the same remote address and a nearly identical time of submission.

\section{Results and Discussion}

Data reduction and screening. To reduce noise in the data, we screened the data submissions according to several criteria (see Reips, 2002b). First, the remote addresses of the data submissions were checked for multiple submissions. Second, the correspondence between self-reported age and education level was checked for unlikely combinations. Third, we excluded all persons under the age of 18, all nonnative English speakers (17\% of the sample), and submissions with considerable missing data, such as people who did not complete the writing task. The screening process yielded a final sample of 58 people ( 33 women and $25 \mathrm{men})$. Ages ranged from 18 to 53 years $(M=$ 29 years, $S D=10.1$, median $=25$ ). Including all the cases did not change the results substantially.

The respondents were divided evenly between the two conditions (30 in the self-novelty condition and 28 in the control condition). The three subscales of the situational self-awareness scale showed acceptable levels of reliabil- 
Table 1

Effects of the Self-Novelty Manipulation on the Situational Self-Awareness Scale: Experiment 1

\begin{tabular}{|c|c|c|c|c|}
\hline \multirow[b]{2}{*}{ Measure } & \multicolumn{2}{|c|}{ Self-Novelty Condition } & \multicolumn{2}{|c|}{ Neutral Condition } \\
\hline & $M$ & $S D$ & $M$ & $S D$ \\
\hline Private & 5.83 & 0.87 & 4.88 & 1.15 \\
\hline Public & 3.97 & 1.67 & 4.56 & 1.61 \\
\hline Surroundings & 5.50 & 1.17 & 4.81 & 1.31 \\
\hline
\end{tabular}

Note $-n=30$ in the self-novelty condition; $n=28$ in the neutral condition. Scores range from 1 to 7 , with higher numbers reflecting greater self-focused attention.

ity as measured by Cronbach's alpha, particularly for threeitem scales (private $\alpha=.74$; public $\alpha=.82$; surroundings $\alpha=.79$ ).

Effects of self-novelty on self-awareness. As was expected, the people in the self-novelty condition reported significantly higher scores on the private self-awareness subscale $[t(56)=3.56, p<.001, d=0.94]$. (All effect sizes were computed with Minsize 2; Morse, 1999.) Table 1 presents the descriptive statistics. No predictions had been made for the other subscales, but they were explored as well. The manipulation did not affect scores on the public subscale $[t(56)=1.37, p<.18, d=0.36]$. A significant effect appeared on the surroundings subscale $[t(56)=$ 2.12, $p<.038, d=0.56]$, reflecting higher scores by the people in the self-novelty condition.

Experiment 1 thus offers support for the validity of the self-novelty manipulation for Internet-based experiments. The people who completed the self-novelty task showed higher levels of self-focused attention. The no-writing control group used in this experiment allowed a test of whether the self-novelty task increased self-focus beyond baseline levels. A disadvantage of this design, however, is that it cannot rule out the possibility that writing anything at all may have increased self-focus. The subsequent experiments thus included various neutral-writing control groups, rather than a no-writing group.

\section{EXPERIMENT 2 Group Context}

In Experiment 2, we explored the validity of the selfnovelty manipulation for running participants in large groups. Conventional manipulations, such as mirrors and video cameras, are impractical for group experiments. A manipulation suitable for data collection in groups would thus expand the methodological possibilities for laboratorybased self-awareness research.

\section{Method}

Participants and Design. A total of 88 undergraduate students (67 women and 21 men) participated as part of a research participation option. Each person was randomly assigned to one of two conditions (self-novelty writing task vs. neutral-writing task).

Procedure. The participants were run in groups of 8-20 people. Each person completed either the self-novelty writing task or a neutralwriting task. Experiment 2 thus included a different control condition than did Experiment 1, which used a no-writing control group.
The participants in the self-novelty condition responded to three questions. The questions resembled the items from Experiment 1, but they were modified so as to be more relevant to a college sample: (1) What is it about you that makes you different from your family? (2) What is it about you that makes you different from your friends? and (3) What is it about you that makes you different from other students at your university? The people in the control condition responded to questions that should not be self-focusing: (1) Please tell us about your psychology class and one of your other classes, and (2) Please describe the last time you went out to eat. After completing the writing task, the participants completed the "Linguistic Implications Form," a 20-item measure of self-focused attention. This measure, developed by Wegner and Giuliano (1980, 1983), involves completing sentences by selecting one of several correct pronouns (e.g., "The noise got to [us, them, me] before long"). Selecting more first-person singular pronouns reflects higher self-focus (cf. D. Davis \& Brock, 1975).

\section{Results}

Data reduction. The pronoun task was coded using the conventional scoring system. First-person singular pronouns were assigned a 1 ; all other pronouns were assigned a 0 . The level of self-focused attention was then expressed as the proportion of sentences completed with the first-person singular option. We computed separate scores for the first 10 items and for the full 20-item scale, since some studies have shown that the first 10 items are more effective than the full scale (e.g., Silvia \& Abele, 2002).

Effects of self-novelty on self-focused attention. No main effects or interactions involving gender appeared (all $F_{\text {s }}<1$ ), so this variable was not considered further. We conducted $t$ tests to see whether the self-novelty writing task significantly affected levels of self-focused attention. This analysis was significant for the first 10 items $[t(86)=$ $3.26, p<.002, d=0.69]$ and for the full 20 items $[t(86)=$ $2.9, p<.005, d=0.62]$. As was expected, the people in the self-novelty condition were more self-focused than were the people in the control condition. Table 2 displays the descriptive statistics. The variances were nearly unequal for the full 20-item scale, so nonparametric analyses were conducted as well. Mann-Whitney tests showed that the people in the self-novelty condition reported significantly greater self-focus than did the people in the neutral condition, for both the first 10 items $\left(Z=2.85, p<.004, \eta^{2}=.094\right)$ and the full 20 -item scale $\left(Z=2.45, p<.014, \eta^{2}=.069\right)$.

\section{Discussion}

Experiment 2 offered support for the validity of the self-novelty manipulation of self-focused attention in a laboratory context. People who wrote about how they dif-

Table 2

Effects of the Self-Novelty Manipulation on a Pronoun Selection Measure of Self-Focus: Experiment 2

\begin{tabular}{lccccr}
\hline & \multicolumn{2}{c}{ Self-Novelty Condition } & & \multicolumn{2}{c}{ Neutral Condition } \\
\cline { 2 - 3 } \cline { 5 - 6 } Items & $M$ & $S D$ & & $M$ & $S D$ \\
\hline First 10 & .52 & .18 & & .41 & .14 \\
All 20 & .48 & .16 & & .40 & .11 \\
\hline
\end{tabular}

Note $-n=44$ in each condition. Scores on the pronoun task range from 0 to 1 , with higher numbers reflecting greater self-focused attention. 
fered from other people were significantly more self-focused on a subsequent pronoun selection measure, relative to people who wrote about neutral topics. An ancillary finding is that the 10 -item version of the pronoun selection task yielded slightly larger effect sizes than did the 20item version, for both the parametric analyses $(d=0.69$ vs. $d=0.62)$ and the nonparametric analyses $\left(\eta^{2}=.094\right.$ vs. $\eta^{2}=.069$ ). These differences are not large, but they coincide with the speculations of past research and can inform future work with this measure.

One might suggest that the difference between the selfnovelty group and the neutral-writing group is attributable to the neutral-writing task. Although we hypothesized that the self-novelty task increased self-focus, perhaps writing about self-irrelevant topics reduced self-focus. This suggestion is implausible in light of the findings from Experiment 1 , which used a no-writing control group. Given that the self-novelty task increased self-focus beyond baseline levels (Experiment 1) and beyond a neutral-writing task (Experiments 2 and 3), the most plausible conclusion is that the self-novelty writing task was responsible for the effect.

\section{EXPERIMENT 3 Group Context}

In Experiment 3, we sought additional validation of the self-novelty task within a laboratory context. A different measure of self-focused attention - the private selfconsciousness scale-was included. Although typically used to measure individual differences in self-focused attention (Fenigstein, Scheier, \& Buss, 1975), this scale is sensitive to situational variations (Osberg, 1985; Wood, Saltzberg, \& Goldsamt, 1990).

\section{Method}

Participants and Design. A total of 74 undergraduate students participated as part of a research participation option. Each person was randomly assigned to one of two conditions (self-novelty writing task vs. neutral-writing task). One person was excluded due to substantial missing data, leaving a final sample of 73 people ( 47 women and 26 men).

Procedure. People participated in groups of $8-14$. The experimenter explained that the experiment was about personality and college life. People expected to complete several measures of personality and then describe their experiences at college. People received a questionnaire containing the manipulation and the measure of selffocused attention. The first sheet was the writing task used in Experiment 2. Half of the people completed the self-novelty form, and the other half completed the neutral form. The second page of the questionnaire contained the private self-consciousness scale (Fenigstein et al., 1975). This 10 -item self-report scale includes items such as "I'm always trying to figure myself out" and "I reflect about myself a lot"; two items are reverse scored. People responded on 7-point scales ranging from 1 (not at all) to 7 (very much).

\section{Results and Discussion}

After reverse-scoring the appropriate items, we averaged the 10 items in the private self-consciousness scale to form a single score. Internal consistency was acceptable $(\alpha=.67)$ and similar to that in past studies (Fenigstein et al., 1975). As was expected, people in the self-novelty condition were more self-focused than were people in the control condition $[t(71)=2.97, p<.004, d=0.699]$. Gender did not participate in any significant effects (all $F$ s $<1$ ). Table 3 displays the descriptive statistics. Experiment 3 thus further supports the validity of the selfnovelty manipulation of self-focused attention for group contexts.

\section{ADDITIONAL VALIDATION RESEARCH}

Previous research with the self-novelty manipulation shows that the writing task replicates conventional selfawareness manipulations. In a series of experiments on emotions (Silvia, 2002a, 2002b), people were induced into different emotional states, self-awareness was manipulated, and emotional intensity was measured. Manipulating self-awareness with a mirror reduced the intensity of emotional experience; manipulating self-awareness with the self-novelty task showed the same effect (Silvia, 2002a, Experiment 2). Another experiment induced selfawareness and measured the salience of death-related thoughts (Silvia, 2001). The self-novelty task and the mirror had the same effects, relative to a control condition. (Both of these experiments were conducted in the laboratory, and the participants were run individually.)

A recent Internet experiment further validates the selfnovelty manipulation for on-line research (Eichstaedt \& Silvia, 2003, Experiment 2). This study measured selffocused attention with an implicit measure. In this measure, people view a "dynamic display" (Eichstaedt, 2003) that flashes words related to semantic categories. When semantic content is salient, people recognize words related to the content more quickly (Eichstaedt, 2002). The implicit measure of self-awareness flashes self-relevant words and neutral words and measures how long it takes people to recognize the words. In one experiment, people completed the self-novelty writing task or a neutral-writing task (describing one's computing environment) or did no writing. People who completed the self-novelty task recognized self-relevant words significantly more quickly than did people who wrote about neutral topics $(d=0.86)$ or who did no writing $(d=1.23)$. This experiment is noteworthy because it validates the manipulation with a new measure of self-focus and further demonstrates the usefulness of the manipulation for Internet contexts. Furthermore, the experiment showed that neutral-writing and nowriting control groups had equivalent effects. This shows (1) that merely writing anything at all will not increase

Table 3

\begin{tabular}{lcc}
\multicolumn{3}{c}{$\begin{array}{c}\text { Effects of the Self-Novelty Manipulation on the Private } \\
\text { Self-Consciousness Scale: Experiment } \mathbf{3}\end{array}$} \\
\hline & Self-Novelty Condition & Neutral Condition \\
\hline$S D$ & 5.13 & 4.64 \\
$S D$ & 0.69 & 0.71 \\
\hline
\end{tabular}

Note $-n=37$ in the self-novelty condition; $n=36$ in the neutral condition. Scores on the private self-consciousness scale range from 1 to 7 , with higher numbers reflecting greater self-focused attention. 
self-focus (as was noted in Experiment 1) and (2) that the self-novelty condition caused the difference between the groups observed in Experiments 2 and 3.

\section{GENERAL DISCUSSION}

An extensive literature describes the effects of selffocused attention on a wide range of outcomes (Carver, 2003; Duval \& Silvia, 2001). Most of the experimental work has been conducted in conventional laboratory settings. Researchers who want to manipulate self-awareness in Internet studies or to run participants in groups cannot use the widely known and well-validated manipulations. This article has described a self-novelty writing task that manipulates self-awareness. The task is brief, easy to work into a procedure, and practical for group and Internet research. Three experiments - one over the Internet and two with groups - showed that the manipulation had the expected effects on self-focused attention, as measured by the situational self-awareness scale (Govern \& Marsch, 2001), the pronoun selection task (Wegner \& Giuliano, 1980), and the private self-consciousness scale (Fenigstein et al., 1975). The manipulation's effect size $(d)$ varied from 0.94 in the Internet sample to 0.69 in each of the laboratory samples. The significant effects on several measures of self-focus gives us greater confidence in the validity of the manipulation.

The self-novelty manipulation is flexible in several respects. First, the control conditions are flexible. Control conditions in which no writing is done, as well as conditions in which neutral topics are written about, can be equally appropriate. Some of our experiments used no-writing control groups (Experiment 1), thus showing that the task increases self-focus beyond unmanipulated, baseline levels. Other experiments involved writing about topics that should not arouse self-novelty (college classes and going out to eat; Experiments 2 and 3). An experiment that used both no-writing and neutral-writing (describing one's computing environment) control groups showed no difference between the control groups (Eichstaedt \& Silvia, 2003); each control group was less self-focused than the self-novelty group. Second, the items used in the manipulation can be modified for different populations. For the student samples (Experiments 2 and 3), people wrote about how they differed from their family and friends and from other students at their university. For the Internet samples (Experiment 1; Eichstaedt \& Silvia, 2003, Experiment 2), people wrote about how they differed from their family and friends and from people in general. Changing the final reference group should strengthen the manipulation for the particular group of participants.

In these experiments, we did not code the content of the self-novelty writing task beyond confirming that people completed the task. Early in our research, we explored possible coding systems for considering how different content might predict self-focused attention, but we were unsuccessful. Ironically, everyone was unique in the same ways. In the student samples, almost all the people said that they differed from other college students because they studied harder, thought deeper, drank less, and took their religion more seriously. We abandoned coding because it seemed unproductive and our primary interest was creating between-conditions differences that replicated conventional laboratory manipulations. Of course, researchers could develop a coding system and take a more differentiated look at how self-content affects self-awareness and other outcomes. For the purposes of manipulating selfawareness in Internet and group contexts, however, coding the content of the writing task is not essential.

Finally, we should emphasize the advantages of this method for Internet-based experiments on self-focused attention. Web-based research has many advantages, such as access to large numbers of participants and to interesting populations that are ordinarily out of reach (Birnbaum, 2001; Reips, 2002a, 2002b). The largest advantage may be the convergent validity that comes from replicating an effect across diverse methods and samples, such as when findings are replicated across Web-based and laboratory experiments. Few manipulations of self-focus are feasible for Internet-based data collection, thus limiting the scope of self-awareness research. Moreover, the new induction method might be useful for researchers interested in how self-awareness participates in computermediated communication (e.g., Postmes, Spears, \& Lea, 1998). Interaction via computers does not necessarily lower inhibitions and increase deindividuation (Postmes $\&$ Spears, 1998). An induction of self-focus that is easily administered over the Internet could be particularly useful for this area of research.

\section{REFERENCES}

BiRnBAUM, M. H. (2001). Introduction to behavioral research on the Internet. Upper Saddle River, NJ: Prentice-Hall.

Carver, C. S. (2003). Self-awareness. In M. R. Leary \& J. P. Tangney (Eds.), Handbook of self and identity (pp. 179-196). New York: Guilford.

Carver, C. S., \& Scheier, M. F. (1978). Self-focusing effects of dispositional self-consciousness, mirror presence, and audience presence. Journal of Personality \& Social Psychology, 36, 324-332.

DAvis, D., \& Brock, T. C. (1975). Use of first-person pronouns as a function of increased objective self-awareness and performance feedback. Journal of Experimental Social Psychology, 11, 381-388.

DAVIS, R. N. (1999). Web-based administration of a personality questionnaire: Comparison with traditional methods. Behavior Research Methods, Instruments, \& Computers, 31, 572-577.

Duval, T. S., \& Lalwani, N. (1999). Objective self-awareness and causal attributions for self-standard discrepancies: Changing self or changing standards of correctness. Personality \& Social Psychology Bulletin, 25, 1220-1229.

Duval, T. S., \& Silvia, P. J. (2001). Self-awareness and causal attribution: A dual-systems theory. Boston: Kluwer Academic.

Duval, T. S., \& Silvia, P. J. (2002). Self-awareness, probability of improvement, and the self-serving bias. Journal of Personality \& Social Psychology, 82, 49-61.

Duval, T. S., \& Wicklund, R. A. (1972). A theory of objective selfawareness. New York: Academic Press.

Duval, T. S., \& Wicklund, R. A. (1973). Effects of objective selfawareness on attributions of causality. Journal of Experimental Social Psychology, 9, 17-31.

EichstaedT, J. (2002). Measuring differences in pre-activation on the Internet: The content category superiority effect. Experimental Psychology, 49, 283-291. 
Eichstaedt, J. (2003). Magnifying the effects of word familiarity and prototypicality on visual word recognition: A dynamic display for Internet-based experiments. Manuscript submitted for publication.

Eichstaedt, J., \& Silvia, P. J. (2003). Noticing the self: Implicit assessment of self-focused attention using word recognition latencies. Social Cognition, 21, 349-361.

Fenigstein, A., Scheier, M. F., \& Buss, A. H. (1975). Public and private self-consciousness: Assessment and theory. Journal of Consulting \& Clinical Psychology, 43, 522-527.

Geller, V., \& Shaver, P. (1976). Cognitive consequences of selfawareness. Journal of Experimental Psychology, 12, 99-108.

Govern, J. M., \& Marsch, L. A. (2001). Development and validation of the situational self-awareness scale. Consciousness \& Cognition, 10, 366-378.

HYATT, C. W., \& HopKINs, W. D. (1994). Self-awareness in bonobos and chimpanzees: A comparative perspective. In S. T. Parker, R. W. Mitchell, \& M. L. Boccia (Eds.), Self-awareness in animals and humans (pp. 248-253). Cambridge: Cambridge University Press.

ICKes, W. J., Wicklund, R. A., \& Ferris, C. B. (1973). Objective self awareness and self esteem. Journal of Experimental Social Psychology, 9, 202-219.

INGRAM, R. E. (1990). Self-focused attention in clinical disorders: Review and a conceptual model. Psychological Bulletin, 107, 156-176.

Kieley, J. M. (1996). CGI scripts: Gateways to World-Wide Web power. Behavior Research Methods, Instruments, \& Computers, 28, 165-169.

KoffKa, K. (1935). Principles of Gestalt psychology. New York: Harcourt, Brace.

Krantz, J. H., \& Eagley, B. M. (1996). Creating psychological tutorials on the World-Wide Web. Behavior Research Methods, Instruments, \& Computers, 28, 156-160.

Mayer, F. S., Duval, T. S., Holtz, R., \& Bowman, C. (1985). Selffocus, helping request salience, felt responsibility, and helping behavior. Personality \& Social Psychology Bulletin, 11, 133-144.

Morse, D. T. (1999). MINSIZE2: A computer program for determining minimum sample size for statistical significance for univariate, multivariate, and nonparametric tests. Educational \& Psychological Measurement, 59, 518-531.

Mullen, B. (1983). Operationalizing the effect of the group on the individual: A self-attention perspective. Journal of Experimental Social Psychology, 19, 295-322.

O’NeIL, K. M., \& Penrod, S. D. (2001). Methodological variables in Web-based research that may affect results: Sample type, monetary incentives, and personal information. Behavior Research Methods, Instruments, \& Computers, 33, 226-233.

O’Neil, K. M., Penrod, S. D., \& Bornstein, B. H. (2003). Web-based research: Methodological variables' effects on dropout and sample characteristics. Behavior Research Methods, Instruments, \& Computers, 35, 217-226.

Osberg, T. M. (1985). Order effects in the administration of personality measures: The case of the Self-Consciousness Scale. Journal of Personality Assessment, 49, 536-540.

Pasveer, K. A., \& Ellard, J. H. (1998). The making of a personality inventory: Help from the WWW. Behavior Research Methods, Instruments, \& Computers, 30, 309-313.

Petrit, F. A. (2002). A comparison of World-Wide Web and paper-andpencil personality questionnaires. Behavior Research Methods, Instruments, \& Computers, 34, 50-54.

Postmes, T., \& Spears, R. (1998). Deindividuation and antinormative behavior: A meta-analysis. Psychological Bulletin, 123, 238-259.
Postmes, T., Spears, R., \& Lea, M. (1998). Breaching or building social boundaries? SIDE-effects of computer-mediated communication. Communication Research, 25, 689-715.

Povinelli, D. J., \& Prince, C. G. (1998). When self met other. In M. Ferrari \& R. J. Sternberg (Eds.), Self-awareness: Its nature and development (pp. 37-107). New York: Guilford.

REIPS, U.-D. (2002a). Internet-based psychological experimenting: Five dos and five don'ts. Social Science Computer Review, 20, 241-249.

ReIPS, U.-D. (2002b). Standards for Internet-based experimenting. Experimental Psychology, 49, 243-256.

Schwartz, A. (1998). Tutorial: Perl, a psychologically efficient reformatting language. Behavior Research Methods, Instruments, \& Computers, 30, 605-609.

SiLVIA, P. J. (2001). Nothing or the opposite: Intersecting terror management and objective self-awareness. European Journal of Personality, 15, 73-82.

SILVIA, P. J. (2002a). Self-awareness and emotional intensity. Cognition \& Emotion, 16, 195-216.

SiLVIA, P. J. (2002b). Self-awareness and the regulation of emotional intensity. Self \& Identity, 1, 3-10.

Silvia, P. J., \& ABELE, A. E. (2002). Can positive affect induce self-focused attention? Methodological and measurement issues. Cognition \& Emotion, 16, 845-853.

Silvia, P. J., \& Duval, T. S. (2001a). Objective self-awareness theory: Recent progress and enduring problems. Personality \& Social Psy chology Review, 5, 230-241.

Silvia, P. J., \& DuVAL, T. S. (2001b). Predicting the interpersonal targets of self-serving attributions. Journal of Experimental Social Psychology, 37, 333-340

Silvia, P. J., \& Duval, T. S. (2004). Self-awareness, self-motives, and self-motivation. In R. A. Wright, J. Greenberg, \& S. S. Brehm (Eds.), Motivational analyses of social behavior: Building on Jack Brehm's contributions to psychology (pp. 57-75). Mahwah, NJ: Erlbaum.

Silvia, P. J., \& PhILLIPS, A. G. (2004). Self-awareness, self-evaluation, and creativity. Personality \& Social Psychology Bulletin, 30, 10091017.

SnOw, C. J., Duval, T. S., \& Silvia, P. J. (in press). When the self stands out: Figure-ground effects on self-focused attention. Self \& Identity.

SpurR, J. M., \& Stopa, L. (2002). Self-focused attention in social phobia and social anxiety. Clinical Psychology Review, 22, 947-975.

Wegner, D. M., \& Giuliano, T. (1980). Arousal-induced attention to self. Journal of Personality \& Social Psychology, 38, 719-726.

Wegner, D. M., \& GiUliano, T. (1983). On sending artifact in search of artifact: Reply to McDonald, Harris, and Maher. Journal of Personality \& Social Psychology, 44, 290-293.

WeGNER, D. M., \& SCHAEFER, D. (1978). The concentration of responsibility: An objective self-awareness analysis of group size effects in helping situations. Journal of Personality \& Social Psychology, 36, 147-155.

WiCKLUND, R. A., \& DuvAL, T. S. (1971). Opinion change and performance facilitation as a result of objective self-awareness. Journal of Experimental Social Psychology, 7, 319-342.

Wood, J. V., Saltzberg, J. A., \& Goldsamt, L. A. (1990). Does affect induce self-focused attention? Journal of Personality \& Social Psychology, 58, 899-908.

(Manuscript received August 29, 2002;

revision accepted for publication September 9, 2003.) 